\title{
Number of fine Particles' and their Mass Concentration: Comparison of Emission of New Printing Technology Versus Traditional Laser Technology
}

\author{
Linda Paegle \\ Rīga Stradinšs University \\ Institute of Occupational Safety and \\ Environmental Health \\ Riga, Latvia \\ Linda.Paegle@rsu.lv \\ Ilona Pavlovska \\ Rīga Stradiňš University \\ Institute of Occupational Safety and \\ Environmental Health \\ Riga, Latvia \\ Ilona.Pavlovska@rsu.lv
}

\author{
Žanna Martinsone \\ Rīga Stradiňš University \\ Institute of Occupational Safety and \\ Environmental Health \\ Riga, Latvia \\ Zanna.Martinsone@rsu.lv \\ Lāsma Akūlova \\ Rīga Stradiņš University \\ Institute of Occupational Safety and \\ Environmental Health \\ Riga, Latvia \\ Lasma.Akulova@rsu.lv
}

\author{
Ivars Vanadzin̄š \\ Rīga Stradiňs University \\ Institute of Occupational Safety and \\ Environmental Health \\ Riga, Latvia \\ Ivars.Vanadzins@rsu.lv
}

\begin{abstract}
For many years the printers have been essential part of our offices and exposures from various printing technologies have been widely researched. The main objective of this study was to compare emitted number and mass of fine particles from laser printers and new Micro Piezo technology ink jet printers during the printing process and one hour afterwards as these emissions have potential for negative health effects.
\end{abstract}

Air samples were taken with the particle size spectrometer for real-time ELPI+, Dekati (air flow rate $10 \mathrm{l} / \mathrm{min}$ ). Measurements were taken $\sim 0.5 \mathrm{~m}$ from the printers: one hour before the test, during printing and one hour afterwards. Similar class black\&white (b/w) and colour printer of each technology were tested. Each printer performed a 10-page and a 100page test according to ECMA 328-1 Standard [1].

During laser printer tests from 8324 to 19943 $\mathrm{pt} / \mathrm{cm}^{3}$ fine particles were determined on printing phase from $b / w$ and colour printers. Ink jet (Micro Piezo) printers produced less: from 3239 to 5247 $\mathrm{pt} / \mathrm{cm}^{3}$. One hour after the printing phase for both types of laser printers' there were 54722 to 152351 $\mathrm{pt} / \mathrm{cm}^{3}$ particles in air and 4270 to $9579 \mathrm{pt} / \mathrm{cm}^{3}$ particles for ink jet printers. Detected particle mass differences was insignificant: in range of 0.002 to $0.012 \mathrm{mg} / \mathrm{m}^{3}$ for laser printers and 0.002 to $0.019 \mathrm{mg} / \mathrm{m}^{3}$ for ink jet printers. Micro Piezo technology printers emitted mass particles were with bigger median size $\mu \mathrm{m}$.
The highest number of particles was observed one hour after the printing for both tested printer technologies. Laser printers' emitted 2.5 to 3.8 times more particles in printing phase and 12.8 to 15.9 times more after printing phase. Particle mass in $\mathrm{mg} / \mathrm{m}^{3}$ was detected in the size range $6 \mathrm{~nm}-2.5 \mu \mathrm{m}$ with no significant mass differences.

Keywords - emission, exposure, indoor air quality, laser printer, ink printer, Micro Piezo, particulate matter.

\section{INTRODUCTION}

Nowadays large proportion of people spend their daily lives, whether at home, in an educational establishment or at work, indoors [2]. In some countries, up to even $90 \%$ of everyday life is spent indoors [3]. Since 1991, indoor air quality has deteriorated rapidly, leading to increased rates of illness and death [2].

Indoor air quality is also inseparable from the ambient air and environment: traffic and industrial pollution are often noticed to enter indoor areas through ventilation systems [4], [5], [6]. Indoor air quality is related to a number of indoor environmental factors, such as exposures from construction and furniture materials, as well as emissions during various processes that people do indoors (e.g. cooking, heating of houses etc.) [6], [7], [8].

Employees' complaints about poor air quality in offices are growing year by year due various reasons. 
First, traditional office spaces and other premises are no longer imaginable without various types of office equipment, printers being one of most wide spread source of pollution with various particles and chemicals [8], [9]. After first generation of dot matrix printers replaced largely by ink printers, laser printers are currently the most common type of printers due to their speed, low noise and fast printing capabilities [10].

The fact that laser printers emit various pollutants during their operation was discovered already more than 20 years ago [11]. The most common printer emissions are volatile organic compounds (VOCs) and ozone, but printers also emit large number of ultra fine particles [10]. Gradually, new technologies are being developed for consumers, among these namely, new generation of inkjet printers claiming to be considered as low-emission printers compared to similar speed laser printers. However, so far this technology is better known for printing on various materials and textiles and not so much as a competition to laser technology [12]. Last generation of these inkjet printers claim to be as fast and more economic than laser printers but little is know on their emissions.

This study compared the emitted particulate matter (PM) from laser and Micro Piezo ink jet black and white (b/w) and color printers.

\section{MATERIALS AND METHODS}

\section{A. Test environment}

The comparative testing of printers was chosen to be performed in a real work environment with real work tasks, but with partial control of external influencing parameters. The room in which the printers were located, as well as the room in which one of the measuring devices was located, was demarcated with the closed door with sealing. The presence of a person in printers room during the print tests was avoided and allowed only for technical assistance with the print test, such as restacking of paper, removing of paper jam and similar tasks. If technical problems took more than 5-10 minutes to resolve (such as running out of printer cartridge) the test was stopped and repeated the next day (including a full repetition of the test process and room preparation). Supply ventilation was left in the test room, monitoring before and after each measurement was made to ensure determination of the supply flow rate and measure possible background dust particles.

The total area of the test room was $23.5 \mathrm{~m}^{3}$. Before each test, the walls, floor and horizontal surfaces of the room were cleaned and fresh air exchange was made the day before. There were two tables and one closed cupboard (approximately 5 years old) made from special laboratory grade laminate in the room during the test. Reflective window blinds were used for the windows to avoid changes in the room temperature. Measurements were performed in the period from June to July 2020, development of the research model and compilation of results from May to October 2020. The air temperature during the measurement period was: $23-26^{\circ} \mathrm{C}$; relative humidity: 50-66\%; atmospheric pressure: 746-760 mm Hg.

\section{B. Test description}

There were two types of tests performed on each printer model: a 10-page test and a 100-page print test. The printing process was started manually by supervising staff from a personal computer prepared and equipped for printing. Printers used standard print speed according to the program settings. Depending on the type of test (10 or 100 pages), there was a 1 minute break after the last page was printed. A total of 460-470 pages were printed during the 10-page test, and 1100-1200 pages during the 100page test. The duration of one measurement was on average 60 - 90 minutes. The duration of the test were different, because according to the chosen methodology, the test was concluded when one of the conditions was met - the limit of 1200 pages was reached or 90 minutes had elapsed. The one side of the A4 sheet attached to the ECMA standard Annex A.2 file was printed. For both b/w and color printing, a sample of this standard with $20 \%$ coverage was used. Black and white printer tests required $20 \%$ page coverage for black color, but color printer - 5\% page coverage for each of the 4 basic colors - black, magenta, cyan, yellow. For all tests, the manufacturer's Stora Enso paper Multicopy $80 \mathrm{~g} / \mathrm{m}^{3}$ A4 paper (Made in Sweden, labelled with "Totally Chlorine Free", Nordic Ecolabel” (3044 0044), "EU Ecolabet” (SE/011/01) and "Forest Stewardship Council” (FSC CO15932) was used.

\section{Sample collection and analyze}

Air samples were taken with the particle size spectrometer for real-time ELPI +, Dekati. The Elpi+ impactor classified particles on the so-called stages into 14 fractions by size in the range from $6 \mathrm{~nm}$ to $10 \mu \mathrm{m}$ with a 9.87 lpm sample flow rate using an outlet/inlet pressure, $40 \mathrm{mbar}$, and $1013.3 \mathrm{mbar}$, respectively. The data were saved every second. All ELPI+ measurement files were transferred to Excel spreadsheets for further calculations. The maximum uncertainty for this measuring device is $20 \%$ [13].

Measurements were performed at a distance of $\sim 0.5 \mathrm{~m}$ from the printer under test and at a height of $\sim 1 \mathrm{~m}$ from the floor. ELPI +, Dekati was placed in the adjacent room, inserting the sampling tube into the room through a specially created opening in the wall (see Fig.1). 
Environment. Technology. Resources. Rezekne, Latvia Proceedings of the $13^{\text {th }}$ International Scientific and Practical Conference. Volume 1, 200-205

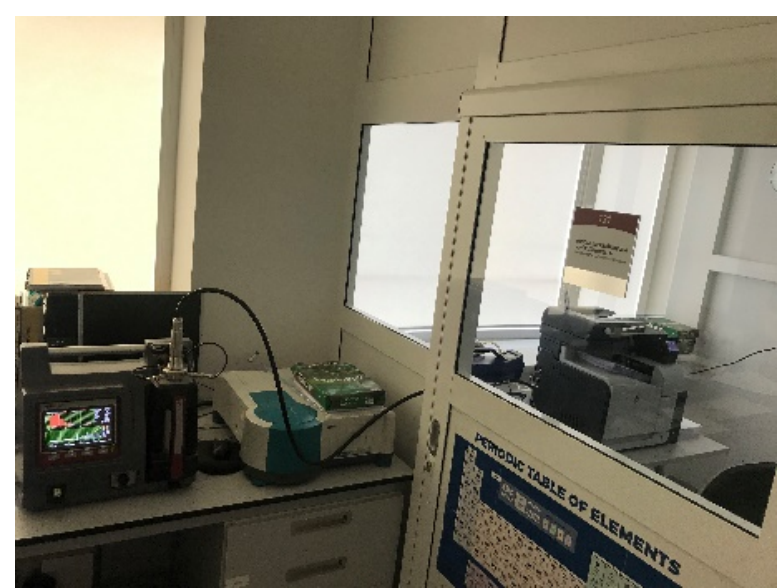

Fig.1. Air sample collection.

Each test consisted of several stages:

- Room background particle pollution measurement. Only the air sample were taken, no people entered the room, the printer did not worked. Duration of the stage 60 minutes;

- $\quad$ Printing test. Printing of 10 or 100 pages was performed according to the already mentioned methodology. The supervisor entered the room only in case of extreme need (for example, the need to supplement the white pages or for the clearing of a paper jam). At the end of this test phase, there were an hour break when the room is closed, but no air sampling, printing or human entry is performed. Duration of the stage 60 - 90 minutes;

- One hour after the end of the print test. No printing is performed in the room, but an air sample is collected. Duration of the stage 60 minutes.

\section{Tested printers}

Four printers were selected by availability for testing. Two of them were b/w and two - colour. One pair (b/w and colour) belonged to the laser printer group according to the specification, and the other - represented new technology - ink printing (Micro Piezo). The selected printer models represented three manufacturers. Original cartridges from the manufacturers and their refills were used for printing. Printers were matched for their average print speed (see Table 1).

\begin{tabular}{|c|c|c|c|}
\hline \multirow[b]{2}{*}{ Printer type } & \multicolumn{3}{|c|}{ Parameters } \\
\hline & $\begin{array}{c}\text { Dimensions } \\
\text { Width } x \text { Depth } \\
\text { x Height), mm }\end{array}$ & Weight, $\mathrm{kg}$ & $\begin{array}{l}\text { Printing } \\
\text { speed for } \\
\text { A4, ppm }\end{array}$ \\
\hline $\begin{array}{l}\text { B/w laser } \\
\text { printer }\end{array}$ & $\begin{array}{l}400 \times 376 \times \\
263\end{array}$ & 11.2 & 33 \\
\hline $\begin{array}{l}\text { B/w ink } \\
\text { printer }\end{array}$ & $\begin{array}{l}375 \times 347 \times \\
302\end{array}$ & 6.4 & 20 \\
\hline $\begin{array}{l}\text { Colour laser } \\
\text { printer }\end{array}$ & $\begin{array}{l}825 \times 915 \times \\
948\end{array}$ & 40.8 & 31 \\
\hline $\begin{array}{l}\text { Colour ink } \\
\text { printer }\end{array}$ & $\begin{array}{l}425 \times 535 \times \\
357\end{array}$ & 18.7 & 24 \\
\hline
\end{tabular}

\section{RESULTS AND DISCUSSION}

When testing particles emitted from printers, either a special camera is used, or the test is performed in a particularly unaffected office environment. Each method has its strengths and limitations. In-chamber experiments are usually performed in a well-controlled environment, reducing the background concentration of particles; however, the size, material, air exchange rate, and other characteristics of the chamber differ from the actual work environment. On the other hand,

measurements in, for example, office cover the concentration of particles in the real world, but face the challenge that other indoor pollutants or factors may also have an impact on the measurement results. At present, determination of the values of nanoparticles emitted from office equipment and assessing the impact on health is especially important as there is growing evidence of effects from poor indoor air to health [14].

The effects on human health are different depending from different sizes of particles. Particles larger than 100 $\mu \mathrm{m}$ can cause eye and nasal mucosal irritation. Dust particles smaller than $100 \mu \mathrm{m}$ form so called fraction of respirable (inhalable) dust; they enter the upper respiratory tract. Particles smaller than $20 \mu \mathrm{m}$ are part of the thoracic dust fraction, while particles smaller than $10 \mu \mathrm{m}$ enter deep airways and often precipitate there. Respirable dusts with a particle size of less than $5 \mu \mathrm{m}$ are the most dangerous to human health, as most of them reach the alveoli as well as the gastrointestinal tract. Ultramicroscopic dust particles can be exhaled again if they do not dissolve and are not rapidly absorbed. Nanoparticles (less than $0.1 \mu \mathrm{m}$ (or $100 \mathrm{~nm}$ )) are able to pass through cell membranes [15].

The number of particles released, their mass, as well as their composition and even diameter, surface area and shape are important and might affect health of workers. The typical size range of particles emitted from printers is 2 - $30 \mu \mathrm{m}$, they are influenced by the design, technical parameters and technology of the printer, as well as the paper used for printing [14]. 


\section{A. $B / w$ printer test comparison}

Comparing the tested b/w laser and ink jet (Micro Piezo) printers of different models, it can be seen that the number of detected particles $\mathrm{pt} / \mathrm{cm}^{3}$ (detection range: $6 \mathrm{~nm}$ - $10 \mu \mathrm{m}$ ) is significantly lower for ink jet printers. Here and in the other results the tendency for the number of particles to be higher not during the printing test, but after it was observed. It could be caused by the condensation processes of the aerosol particles, as well as the fact that the test was performed indoors instead of in a test chamber where emitted particles are perceived faster [14], [16]. Comparing the 10-page test for both types of $\mathrm{b} / \mathrm{w}$ printer models, laser printer detected four times more particles during the print test and more than 16 times after the test. Similar results were observed during the 100-page test: during the test, the number of particles emitted by the b/w laser printer was 2 times higher, but one hour after the test - even 35 times higher than from b/w ink printer (see Table 2). The detected particles were up to $2.5 \mu \mathrm{m}$ in size. No particles in the size range of $2.5-10 \mu \mathrm{m}$ was detected during the tests.

TABLE 2. B/W PRINTER COMPARISON

\begin{tabular}{|c|c|c|c|c|c|c|c|c|c|}
\hline \multirow[b]{2}{*}{ Chanel } & \multirow[b]{2}{*}{$\begin{array}{l}\text { Diameter } \\
\text { / size }\end{array}$} & \multicolumn{2}{|c|}{$\begin{array}{c}\mathrm{B} / \mathrm{w} \text { laser printer } 10 \\
\text { page test, } \mathbf{p t} / \mathbf{c m}^{3}\end{array}$} & \multicolumn{2}{|c|}{$\begin{array}{l}\text { B/w laser printer } 100 \\
\text { page test, } \mathbf{p t} / \mathrm{cm}^{3}\end{array}$} & \multicolumn{2}{|c|}{$\begin{array}{l}\mathrm{B} / \mathrm{w} \text { ink printer } 10 \\
\text { page test, } \mathbf{p t} / \mathrm{cm}^{3}\end{array}$} & \multicolumn{2}{|c|}{$\begin{array}{c}\mathrm{B} / \mathrm{w} \text { ink printer } 100 \\
\text { page test, } \mathrm{pt} / \mathrm{cm}^{3}\end{array}$} \\
\hline & & $\begin{array}{l}\text { Printing } \\
\text { test }\end{array}$ & $\begin{array}{l}1 \text { hour } \\
\text { after }\end{array}$ & $\begin{array}{l}\text { Printing } \\
\text { test }\end{array}$ & $\begin{array}{l}1 \text { hour } \\
\text { after }\end{array}$ & $\begin{array}{l}\text { Printing } \\
\text { test }\end{array}$ & $\begin{array}{l}1 \text { hour } \\
\text { after }\end{array}$ & $\begin{array}{l}\text { Printing } \\
\text { test }\end{array}$ & $\begin{array}{l}1 \text { hour } \\
\text { after }\end{array}$ \\
\hline 1 & 0,01 & 9413 & 83659 & 5772 & 105582 & 0 & 4507 & 2860 & 3238 \\
\hline 2 & 0,02 & 934 & 17685 & 946 & 17523 & 1481 & 749 & 456 & 205 \\
\hline 3 & 0,04 & 1286 & 10379 & 870 & 17259 & 721 & 741 & 442 & 344 \\
\hline 4 & 0,07 & 870 & 3537 & 926 & 8128 & 531 & 669 & 254 & 247 \\
\hline 5 & 0,12 & 778 & 1458 & 531 & 3171 & 266 & 267 & 119 & 129 \\
\hline 6 & 0,20 & 234 & 312 & 161 & 688 & 145 & 110 & 64 & 73 \\
\hline 7 & 0,31 & 102 & 41 & 69 & 0 & 95 & 52 & 49 & 28 \\
\hline 8 & 0,48 & 12 & 0 & 18 & 0 & 41 & 16 & 2 & 4 \\
\hline 9 & 0,76 & 0 & 0 & 1 & 0 & 0 & 1 & 0 & 2 \\
\hline 10 & 1,25 & 0 & 0 & 0 & 0 & 3 & 0 & 1 & 0 \\
\hline 11 & 2,02 & 0 & 0 & 0 & 0 & 1 & 0 & 0 & 0 \\
\hline 12 & 3,02 & 0 & 0 & 0 & 0 & 0 & 0 & 0 & 0 \\
\hline 13 & 4,45 & 0 & 0 & 0 & 0 & 0 & 0 & 0 & 0 \\
\hline 14 & 7,31 & 0 & 0 & 0 & 0 & 0 & 0 & 0 & 0 \\
\hline $\begin{array}{c}\text { Total } \\
\text { number }\end{array}$ & & 13630 & 117071 & 9294 & 152351 & 3285 & 7112 & 4250 & 4270 \\
\hline
\end{tabular}

\section{B. Color printer test comparison}

Color printer technology comparison tests show the same trends - the highest peak of the results was observed one hour after the end of the printing process. The color laser printer detected a higher number of particles during the printing process: 6 times more in the 10-sheet and almost 2 times more in the 100-sheet compared to the color ink jet (Micro Piezo) printer during the printing process. The measurement also shows a higher number of detected particles one hour after printing for the color laser printer manufacturer's model, reaching almost 6 times the specified number of particles during the 10-page test and 14 times the 100-page one hour after test. Particles detected by the color printers are up to $2.5 \mu \mathrm{m}$ in size (see Table 3 ). 
Environment. Technology. Resources. Rezekne, Latvia Proceedings of the $13^{\text {th }}$ International Scientific and Practical Conference. Volume 1, 200-205

TABLE 3. COLOUR PRINTER COMPARISON

\begin{tabular}{|c|c|c|c|c|c|c|c|c|c|}
\hline \multirow[b]{2}{*}{ Chanel } & \multirow[b]{2}{*}{$\begin{array}{l}\text { Diameter } \\
\text { / size }\end{array}$} & \multicolumn{2}{|c|}{$\begin{array}{l}\text { Colour laser printer } \\
10 \text { page test, } \mathrm{pt} / \mathrm{cm}^{3}\end{array}$} & \multicolumn{2}{|c|}{$\begin{array}{l}\text { Colour laser printer } \\
100 \text { page test, } \mathrm{pt} / \mathrm{cm}^{3}\end{array}$} & \multicolumn{2}{|c|}{$\begin{array}{l}\text { Colour ink printer } \\
10 \text { page test, } \mathrm{pt} / \mathrm{cm}^{3}\end{array}$} & \multicolumn{2}{|c|}{$\begin{array}{l}\text { Colour ink printer } \\
100 \text { page test, } \mathrm{pt} / \mathrm{cm}^{3}\end{array}$} \\
\hline & & $\begin{array}{l}\text { Printing } \\
\text { test }\end{array}$ & $\begin{array}{l}1 \text { hour } \\
\text { after }\end{array}$ & $\begin{array}{l}\text { Printing } \\
\text { test }\end{array}$ & $\begin{array}{l}1 \text { hour } \\
\text { after }\end{array}$ & $\begin{array}{l}\text { Printing } \\
\text { test }\end{array}$ & $\begin{array}{l}1 \text { hour } \\
\text { after }\end{array}$ & $\begin{array}{l}\text { Printing } \\
\text { test }\end{array}$ & $\begin{array}{l}1 \text { hour } \\
\text { after }\end{array}$ \\
\hline 1 & 0,01 & 10867 & 25793 & 6554 & 36152 & 1281 & 5994 & 1953 & 5904 \\
\hline 2 & 0,02 & 4940 & 16364 & 0 & 33917 & 795 & 947 & 1454 & 1099 \\
\hline 3 & 0,04 & 1681 & 8780 & 883 & 32616 & 487 & 1332 & 836 & 581 \\
\hline 4 & 0,07 & 749 & 2369 & 345 & 14033 & 253 & 649 & 503 & 504 \\
\hline 5 & 0,12 & 875 & 789 & 281 & 5042 & 223 & 400 & 308 & 224 \\
\hline 6 & 0,20 & 425 & 365 & 170 & 840 & 120 & 184 & 121 & 108 \\
\hline 7 & 0,31 & 301 & 199 & 66 & 245 & 68 & 65 & 59 & 39 \\
\hline 8 & 0,48 & 103 & 63 & 26 & 49 & 9 & 7 & 12 & 7 \\
\hline 9 & 0,76 & 2 & 0 & 1 & 0 & 0 & 0 & 0 & 0 \\
\hline 10 & 1,25 & 0 & 0 & 0 & 0 & 1 & 0 & 1 & 0 \\
\hline 11 & 2,02 & 0 & 0 & 0 & 0 & 2 & 1 & 0 & 0 \\
\hline 12 & 3,02 & 0 & 0 & 0 & 0 & 0 & 0 & 0 & 0 \\
\hline 13 & 4,45 & 0 & 0 & 0 & 0 & 0 & 0 & 0 & 0 \\
\hline 14 & 7,31 & 0 & 0 & 0 & 0 & 0 & 0 & 0 & 0 \\
\hline $\begin{array}{c}\text { Total } \\
\text { number }\end{array}$ & & 19943 & 54722 & 8324 & 122895 & 3239 & 9579 & 5247 & 8465 \\
\hline
\end{tabular}

\section{C.. $\quad$ Detected mass comparison}

Analyzing the mass of the detected particles $\left(\mathrm{mg} / \mathrm{m}^{3}\right)$ in the 10 and 100 page tests at different periods (during the test and one hour after the test), it can be seen that the data obtained did not show important differences and significant concentrations. Detected particle mass from laser printers was from 0.005 to $0.019 \mathrm{mg} / \mathrm{m}^{3}$, but ink jet - 0.002 to $0.012 \mathrm{mg} / \mathrm{m}^{3}$. A more important indicator of this type of comparative test for the assessment of human health effects is the number of particles already described above and particle median size (see Table 4). Median size of particles emitted by laser printers was from 0.116 to $0.539 \mu \mathrm{m}$ but for ink jet -0.990 to $5.267 \mu \mathrm{m}$. The mass values set for both types of printers were similar, the particles produced by the ink jet were larger in size, which has less of impact on human health.

TABLE 4. EMITTED MASS COMPARISON

\begin{tabular}{|c|c|c|c|c|c|c|c|c|}
\hline & \multicolumn{2}{|c|}{10 page test } & \multicolumn{2}{|c|}{ After 10 page test } & \multicolumn{2}{|c|}{100 page test } & \multicolumn{2}{|c|}{ After 100 page test } \\
\hline Printer type & $\begin{array}{l}\text { Mass, } \\
\mathbf{m g} / \mathbf{m}^{3}\end{array}$ & $\begin{array}{l}\text { Median } \\
\text { size, } \mu \mathrm{m}\end{array}$ & $\begin{array}{l}\text { Mass, } \\
\mathbf{m g} / \mathbf{m}^{3}\end{array}$ & $\begin{array}{l}\text { Median } \\
\text { size, } \mu \mathrm{m}\end{array}$ & $\begin{array}{l}\text { Mass, } \\
\mathbf{m g} / \mathbf{m}^{3}\end{array}$ & $\begin{array}{l}\text { Median } \\
\text { size, } \mu \mathrm{m}\end{array}$ & $\begin{array}{l}\text { Mass, } \\
\mathbf{m g} / \mathbf{m}^{3}\end{array}$ & $\begin{array}{l}\text { Median } \\
\text { size, } \mu \mathrm{m}\end{array}$ \\
\hline $\begin{array}{l}\text { B/w laser } \\
\text { printer }\end{array}$ & 0,005 & 0.280 & 0,005 & 0.130 & 0,006 & 0,529 & 0,008 & 0,116 \\
\hline $\mathrm{B} / \mathrm{w}$ ink printer & 0,012 & 2,240 & 0,003 & 0,990 & 0,003 & 1,754 & 0,002 & 5,267 \\
\hline $\begin{array}{l}\text { Colour laser } \\
\text { printer }\end{array}$ & 0,014 & 0,340 & 0,010 & 0,270 & 0,005 & 0,539 & 0,019 & 0,171 \\
\hline $\begin{array}{l}\text { Colour ink } \\
\text { printer }\end{array}$ & 0,011 & 1,250 & 0,007 & 1,111 & 0,004 & 1,425 & 0,002 & 4,710 \\
\hline
\end{tabular}




\section{CONCLUSIONS}

In general, the comparative tests for printers between the $b / w$ printers of different manufacturers, showed that lower number of particles in $\mathrm{pt} / \mathrm{cm}^{3}$ (range of detection: 6 $\mathrm{nm}-10 \mu \mathrm{m}$ but not more than 2,5 $\mu \mathrm{m}$ ) was emitted from ink jet (Micro Piezo) printer. According to the data found in the scientific literature, a large part of research and printer tests have been performed in special test chambers with controlled and constant environmental conditions [17].

In a semi-controlled office space test in Australia, the average particle number achieved during printing was $18,060 \mathrm{pt} / \mathrm{cm}^{3}$ (but no post-printing measures were made). Also in a comparative test of different models of printers in Germany, the median number of particles per $\mathrm{cm}^{3}$ was around 18,000 (with a peak value of $190,000 \mathrm{pt} / \mathrm{cm}^{3}$ ). According to other researchers, the number of captured particles during printing ranges from $12,000 \mathrm{pt} / \mathrm{cm}^{3}$ (with a peak value of $99,000 \mathrm{pt} / \mathrm{cm}^{3}$ ) to $26,000 \mathrm{pt} / \mathrm{cm}^{3}$. Particle measurements after printing and $\mathrm{pt} / \mathrm{cm}^{3}$ of the number of particles detected during printing are not emphasized [17].

The results obtained and summarized are indicative and applicable to the environmental parameters of the day and only to the printer of the tested model that were used for testing. Generalization of results requires longer tests with multiple iterations and comparisons between singleseries printer models. However, this study shows clear tendency that modern inkjet technologies (e.g. Micro Piezo) shows potential for lover exposures to particles in office air.

\section{ACKNOWLEDGMENTS}

Printers for use in this study were supplied by RF Serviss company.

\section{REFERENCES}

[1] ECMA Inernational "Determination of chemical emission rates from electronic equipment - Part 1 (using-consumables)," 9th edition (December 2018) - Part 1 (using-consumables).

[2] H. Ritchie and M. Roser “Indoor Air Pollution,” revised 2019 [online] Available: https://ourworldindata.org/indoor-airpollution\#annual-deaths-from-indoor-air-pollution-have-declinedglobally-by-more-than-1-million-since-1990

[3] J. Sundell "On the history of indoor air quality and health,” Indoor Air, 14 (7), pp. 51-58, 2004.
[4] M. Ścibor, B. Balcerzak, A. Galbarczy, T. Targosz and G. Jasienska. "Are we safe inside? Indoor air quality in relation to outdoor concentration of PM10 and PM2.5 and to characteristics of homes," Sustainable Cities and Society, 48, 2019. https://doi.org/10.1016/j.scs.2019.101537

[5] Q. Y. Meng, B. J. Turpin, L. Korn, C. P. Weisel, M. Morandi et all "Influence of ambient (outdoor) sources on residential indoor and personal PM2.5 concentrations: Analyses of RIOPA data,” Journal of Exposure Science \& Environmental Epidemiology, 15, pp. 1728, 2005.

[6] A. Cincinelli and T. Martellini "Indoor Air Quality and Health," International Journal of Environmental Research and Public Health, 14, 2017. https://doi:10.3390/ijerph14111286

[7] A. P. Jones "Indoor air quality and health," Atmospheric $\begin{array}{llll}\text { Environment, } 33(28), & \text { pp. 4535-4564, } 1999 .\end{array}$ https://doi.org/10.1016/S1352-2310(99)00272-1

[8] The WHO European Centre for Environment and Health, "WHO guidelines for indoor air quality: selected pollutants,” 2010.

[9] C. He, L. Morawska and L. Taplin "Particle Emission Characteristics of Office Printers," Environmental Science \& Technology, 41(17), pp. 6039-6045, 2007. https://doi.org/10.1021/es063049z

[10] Z. M. Wang, J. Wagner and S. Wall “Characterization of Laser Printer Nanoparticle and VOC Emissions, Formation Mechanisms, and Strategies to Reduce Airborne Exposures,” Aerosol Science and Technology, 45(9), 2011. https://doi.org/10.1080/02786826.2011.580799

[11] C. He, L. Morawska, H. Wang, R. Jayaratne, P. McGarry et all. "Quantification of the relationship between fuser roller temperature and laser printer emissions,” Journal of Aerosol Science, 41(6), 2010. https://doi.org/10.1016/j.jaerosci.2010.02.015

[12] O. Motonori and T. Tomoaki "Novel Micro Piezo Technology for Ink Jet Printhead,” International Conference on Digital Printing Technologies, pp. 314-318, 2007.

[13] I. Pavlovska, Ž. Martinsone, I. Vanadziṇš, I. Mārtiṇsone, A. Seile and P. Sudmalis "Occupational exposure parameters for characterization of nanoparticulate matter toxicity: Metal versus wood processing," Process Safety and Environmental Protection, 102, pp.230-237, 2016. https://doi.org/10.1016/j.psep.2016.03.018

[14] J. G. Jianwei, S. Karrasch, T. Salthammer "Review of the characteristics and possible health effects of particles emitted from laser printing devices,” Indoor Air, 30, pp. 396 - 421, 2020. https://doi.org/10.1111/ina.12646

[15] M. Eglīte "Occupational Medicine," Riga: Rīga Stradiṇš University, 2012.

[16] E.Uhde, C. He, M. Wensing "Characterization of Ultra-fine Particle Emissions from a Laser Printer,” Proceedings of Healthy Buildings, 2006.

[17] T. Tang, J. Hurraß, R. Gminski and V. Mersch-Sundermann "Fine and ultrafine particles emitted from laser printers as indoor air contaminants in German offices,” Environmental Science and Pollution Research, 19(9), 2012. doi:10.1007/s11356-011-0647-5 